\title{
Conrail and Liquidation Value: Creditors' and Stockholders' Entitlement in the Regional Rail Reorganization
}

In the spring of 1973 a federal district judge in Pennsylvania supervising the reorganization of the Penn Central railroad warned that the debtor's estate of the railroad was being overwhelmed by operating losses and that train service might have to cease. ${ }^{1}$ The prospect ${ }^{2}$ spurred passage by Congress of a new statute for handling railroad insolvency, the Regional Rail Reorganization Act. ${ }^{3}$ One troublesome question raised by the legislation concerns what compensation must be paid

1. In re Penn Cent. Transp. Co., 355 F. Supp. 1343 (E.D. Pa. 1973) (Fullam, J.).

2. Penn Central has been the major rail carrier in the Northeast and Midwest. It serves 55 percent of all manufacturing plants in the United States, and is the leading carrier of coal, metals, chemicals, automobiles, manufactured consumer goods, and mail. Regional Rail Reorganization Act Cases, 419 U.S. 102, 117 n.12 (1974); H.R. REP. No. 93.620, 93d Cong., Ist Sess. 26 (1973). A study in 1973 by the United States Department of Transportation estimated that an actual abandonment of service by Northeast carriers would cause a 2.7 percent drop in Gross National Product within two months and a 3.0 percent rise in unemployment. Cited in id.; S. REP. No. 93.601, 93d Cong., Ist Sess. 8 (1973).

3. 45 U.S.C. $\$ \$ 701-93$ (Supp. IV 1974) [hereinafter cited as Rail Act]. The Rail Act was intended to supplement the traditional vehicle for reorganization of insolvent interstate railroads, $\$ 77$ of the Bankruptcy Act, I1 U.S.C. $\$ \$ 205-205 a$ (1970), by providing a way to consolidate into one operating company the more profitable lines of various insolvent roads in the Northeast. The Rail Act also provided for the rapid abandonment or sale of lines not suitable for such inclusion, and supplied funds for the restoration of roadbed and track and the satisfaction of protective labor conditions. In contrast, in a traditional $\$ 77$ reorganization, the reorganization trustee and court can do little more than scale down the capital structure of the individual railroad; permission to abandon service on some of the railroad's less profitable lines must be sought in separate lengthy ICC proceedings.

For a brief description of the Rail Act and its planning processes, see G. HiLtoN, ThE. Northeast Railroad Problem 29-43 (Am. Enterprise Inst. for Pub. Pol'y Res. 1975). On the operation of $\$ 77$, see H. Guthmann \& H. Dougall, Corporite Financial. Policy 652-54, 663 (1955); Barber, Railroad Reorganization, Section 77, and the Need for Legislative Reform, 21 U.C.L.A. L. REv. 553 (1973); Fuller, The Background and Techniques of Equity and Bankruptcy Railroad Reorganizations-A Survey, 7 LAw \& ConteMP. PRoB. 377, $384-92$ (1940); Haskell, Raiload Reorganization for Beginners, 24 ALA. L. REv. 295, 296-303 (1972); Swaine, A Decade of Railroad Reorganization under Seclion 77 of the Federal Bankruptcy Act, 56 HaRv. L. Rev. 1193 (1943). For a history of the evolution of the earlier equity receiverships, see II A. Dewing, The Financial Policy of Corporations 1228-56 (5th ed. 1953); H. GutimisN \& H. Dovg.s.t, supra at 646, 648; Fuller, supra at 378-84. 
to the creditors and stockholders of the insolvent roads included under the Act. ${ }^{4}$ Congress has attempted to salvage the Northeastern railroads by stepping outside the framework of wholly private reorganization, instead providing a transfusion of federal loans and requiring the conveyance of rail assets from the insolvent roads to the Consolidated Rail Corporation (Conrail), a federally created company in which the creditors and stockholders will receive participations. In such an assisted reorganization, is it a "taking" to accord creditors and stockholders securities and other benefits worth less than the liquidation value ${ }^{6}$ of the rail assets retained in the reorganized rail system? The problem of defining the entitlement of creditors and stockholders will be addressed for the first time by the Special Court under Judges Friendly, Wisdom, and Thomsen in litigation in 1976.

4. The operating railroads included in the Conrail reorganization anc the Penn Contral, Erie Lackawanna, Lehigh Valley, Reading, Central of $\mathrm{New}$ Jersey, Lehigh and Hudson, and Ann Arbor.

5. "[N]or shall private property be taken for public use, without just compensation." U.S. CoNst. amend. $Y$.

6. "Liquidation value" refers to the amount which can be realized by the sale of rail assets for their most profitable use. This may include sale to other types of busincsse, or to other railroads. If the assets can be used most profitably in existing rail operation, then their liquidation value is of course equal to present going-concen value. But (o) keep the terms distinct, this Note will use "liquidation value" only to describe the amount realized by sale of rail assets for use outside the original railroad enterpu isc. See New Haven Inclusion Cases, 399 U.S. 392, 489, 492 (1970); II J. Bonbright, Tui, Valuation of Property 759, 762 (1937); I A. Dewing. sujua note 3, at 373-75. Unles otherwise specified, references are to net liquidation value-that is, the gross proceds of sale reduced by the expenses of liquidation. If the assets would realize the greatest amount when sold gradually, the procecds must also be discounted to present value.

The liquidation value of the claims of any class of bondholders, unsecured creditors, or stockholders depends not only on the size of the estate of the debtor, but on the rule by which the proceeds of its sale are distributed among classes. In a straight bankruptcy procecding, the claims of each class are treated as matured by the debtor's clefault or petition for bankruptcy. The proceeds of the estate are used first to pay off the principal and accrued interest of the most senior class of bondholders (those with prior liens on the debtor's property), then the claims of subordinated bondholders and the unsecured creditors. Any proceeds that remain revert to the stockholder's residual interest in the bussiness. In the forms of rcorganization traditionally used for railroad insolvencies-the. equity receivership and its successor, $\$ 77$-the practice of treating claims as matured was imported from the straight bankruptcy analogy, with the enunciation of the "absolute priority rule." Ecker v. Western Pac. R.R., 318 U.S. 418, 483 (1943); Northern'Pac. Ry. v. Boyd, 228 U.S. 482, 504-05 (1913). Even though the business is to be continued, the participations in the new enterprise are allocated in the same manner as the proceeds of a liquidation. The most senior class is to be paid off in full on the principal and accrued interest of its claim before any more jumior class is allowed participation.

The absolute priority rule, however, has only governed the allocation of value among classes. The rule does not specify that full "liquidation value" must be accorded to the debtor's estate as a whole.

7. The conveyance of designated rail assets to Conrail is presently expected to occur about April 1, 1976. Wall St. J., Feb. 13, 1976, at 2, col. 2. The entry of the conveyance order by the Special Court will trigger a valuation proceeding: after conveyance, the Special Court is required by statute to decide whether each exchange of properties for 
The question was not passed on by the Supreme Court in the first Rail Act decision in 1974, the Regional Rail Reorganization Act Cases. ${ }^{\mathbf{s}}$ Nor is it rendered moot by the statutory provisions for payment in the Rail Act, for the Act provides that no more than the "constitutional minimum" shall be paid to the rail estates. ${ }^{9}$ Because of the prevalence of the view that the creditors and stockholders of a railroad are constitutionally entitled in a bankruptcy reorganization to the full liqui-

Conrail securities and other benefits is "in the public interest" and "fair and equitable" to the estate of each railroad in accord with the standards of fairness and equity necessary for approval of a plan of reorganization under $\$ 77$. Rail Act $\$ 303(\mathrm{c})(\mathrm{l})(\mathrm{A})$, 45 U.S.C. $\$ 743(\mathrm{c})(1)(\mathrm{A})$ (Supp. IV 1974).

If the terms of any exchange are not fair and equitable, the Special Court has some power to adjust the compensation by reallocating securities among the railroads, ordering the transfer of any undistributed Conrail securitics or United States Railway Association obligations, or entering a judgment against Conrail. Rail Act $\$$ 303(c)(2), 45 U.S.C. $\$ 713(\mathrm{c})($ ()) (Supp. IV 1974). Such measures, howerer, would have little real cffect in increasing the value of securities and other compensation received by the rail cstates. See In re Penn Cent. Transp. Co., 38t F. Supp. 895, $929-31$ (Regional Rail Reorg. Spec. Ct. 1974); Regional Rail Reorganization Act Cases, 419 U.S. 102, 167 (1974) (Douglas, J., dissenting). If there is a shortfall in compensation, and the amount cannot be remedied by the Special Court's limited powers, it is then expected that the rail estates, on behalf of their creditors and stockholders, will file suit in the Court of Claims under the Tucker Act, 28 U.S.C. $\$ 1491$ (Supp. IV 1974). Such a supplemental remedy was found to be available in the initial Rail Act litigation, thus preserving the constitutionality of the Act. Regional Rail Reorganization Act Cases, supra at 125-36, 148.

Whether the Special Court judgment will have preclusive effect on the Court of Claims litigation probably depends on whether the Supreme Court chooses to hear the appeal which can be taken from the Special Court's judgment. (By the terms of the Rail Act, the Supreme Court can dismiss the appeal if it "would not be in the interest of an expeditious conclusion of the proceedings." Rail Act $\$ 303(\mathrm{~d})$, 45 U.S.C. $\$ 743$ (d) (Supp. IV 1974).) The parties in Court of Claims litigation would be different from those bound by the Special Court judgment-suit under the Tucker Act has to be brought against the United States rather than Conrail-so the formal collaterally estopping effect of the judgment would be limited. But any Supreme Court determination of the constitutionally minimum level of compensation would effectively conclude the question in subsequent litigation.

8. 419 U.S. 102 (1974). The Court did note the "distinct possibility" that the estate of Penn Central might suffer a taking, in light of the huge $\$ 8551$ million net loss suffered by Penn Central between mid-1970 and 1973, $i d$. at 124 , and the risk that the reorganization plan for Conrail might not be implemented within a reasonable period. But the question of how to value the properties transferred to Comrail was spccifically reserved. $I d$, at 147 n.34. The Special Court also left the question open. In re Penn Cent. Transp. Co., 384 F. Supp. 895,928 n.61 (Regional Rail Reorg. Spec. Ct. 1974).

9. If the special court finds that the terms of one or more conveyances or exchanges for securities or other benefits are fairer and more equitable than is required as a constitutional minimum, then it shall order the return of any excess securities, obligations, or compensation to the [Consolidated Rail] Corporation or a profitable railroad so as not to exceed the constitutional minimum standard of fairness and equity.

Rail Act $\$ 303(\mathrm{c})(3), 45$ U.S.C. $\$ 743(\mathrm{c})(3)$ (Supp. IV 1974) (cmphasis added). See also id. $\$ 303(\mathrm{c})(\mathrm{1})(\mathrm{B}), 45$ U.S.C. $\$ 743(\mathrm{c})(1)(\mathrm{B})$ (Supp. IV 1974). The directive to the Special Court to recapture any compensation above the constitutional minimum amounts to a proupective incorporation of the court's decision on what constitutes a taking in the Rail Act reorganization. Thus, cren if Conrail is extremely successful, with prospects of high going-concern value, the constitutional question of the minimum compensation due creditors and stockholders in a rcorganization apparently must be reached. 
dation value of the carrier's property, ${ }^{10}$ it seems appropriate to examine the constitutional and historical plausibility of the claim.

\section{The Interests of Creditors and Stockholders vs. the Interest of Rail Users}

The situation of the Northeastern railroads has exposed the possible opposition between the interests of railroad creditors and stockholders in the recovery of their investment and the interest of the public in continued service. In earlier railroad insolvencies the use of federal bankruptcy power to suspend creditors' foreclosure rights and effect a reorganization did not always pose the conflict so clearly. If the going-concern value of a railroad exceeded the liquidation value of its assets for nonrail purposes, then junior creditors and perhaps even the stockholders would benefit by continuation of the enterprise as much as would the railroad's patrons.

10. In the initial litigation in 1974 over the constitutionality of the Regional Rail Reorganization Act establishing Conrail, Judge Fullam, as part of the three-judge district court which held the Act unconstitutional, took the position in his concurrence that the projected value of the securities accorded the rail estates must be "at least liquidation value [of the assets] plus interim erosion." Connecticut Gen. Ins. Corp. v. United States Ry. Ass'n, 383 F. Supp. 510, 533 (E.D. Pa. 1974) (footnote omitted) (Fullam, J., concurring), rev'd on other grounds sub nom. Regional Rail Reorganization Act Cases, 419 U.S. 102 (1974).

The Penn Central and New Haven bankruptcy trustees have contended that the constitutional minimum is at least liquidation value. See Bricf for Appellants, Trustces of the Property of Penn Cent. Transp. Co., at 55, Regional Rail Reorganization Act Cases, supra ("Fair market value is the constitutional minimum because . . . if a railroad has neither earnings nor the reasonable prospect of earnings, its owners have a constitutional right to withdraw their property from operation by them as a railroad and to realize the value obtainable from its sale."); Brief of Cross-Appellant, Trustec of the Property of New York, N.H. \& H.R.R., at 61-68, Regional Rail Reorganization Act Cases, supra.

In the appeal from the three-judge Connecticut General decision, the United States Railway Association (USRA) contended that payment of liquidation value was not constitutionally required if a "profitable" reorganization could be effected through Conrail. USRA instead proposed payment of "substantial going-concern" value as sufficient. Sec Brief of Appellee and Cross-Appellee United States Ry. Ass'n at 11, Regional Rail Reorganization Act Cases, supra (" $[W]$ here a railroad can be reorganized to have a substantial going-concern value, that value is the measure of the investors' rights even if nct liquidation value would be higher.") However, in the "Final System Plan" for or* ganizing Conrail, issued by the Railway Association on July 26, 1975, and allowed to become effective on November 8,1975 , by Congress's inaction (N.Y. Times, Nov. 9, 1975 at 1, col. 5), USRA offered no conclusion about the constitutional minimum deserved by rail estates in a rcorganization. I United States RAILway Association, Findi. System Plan 122-23 (July 26, 1975) [hereinafter cited as Final Systear Plan].

See Comment, The Secured Creditor's Right to Full Liquidation Value in Corporate Reorganization, 42 U. CHI. L. Rev. 510, 529 (1975) ("Although the remedial rights of a secured creditor can be regulated in the interest of accomplishing successful corporate reorganizations, such regulation violates the fifth amendment of the Constitution when it impairs the liquidation value of the creditor's lien without compensation."); Note, Takings and the Public Interest in Railroad Reorganization, 82 YaLE L.J. 1001, 1005 (1973) (creditors constitutionally entitled to pre-bankruptcy liquidation value). 
The condition of the railroads to be included in Conrail is quite different. Penn Central has had no net operating income for at least five years. ${ }^{11}$ In contrast, the net liquidation value of Penn Central rail properties may be as high as $\$ 1.99$ billion. ${ }^{12}$ It is true that the Rail Act reorganization has been designed to allow a major restructuring of rail operations and could justify more optimistic income prospects; both Penn Central creditors and the United States Railway Association agree that Conrail can be operated to have some net income by 1985.1: But estimates of Conrail's income vary widely, and the Special Court may very possibly conclude that the going-concern value underlying the distributed Conrail securities is less than the liquidation value of the assets transferred to Conrail.

11. Penn Central had net operating income from its rail opcrations in only onc year between 1964 and 1970. Its loss on rail services reached a pre-bankruptcy high of $\$ 193$ million in 1969. See Staff Report of the SEC to the Special Subcomir. ox INVestig.itions, House Comm. on Interstate and Foreign Commerce, The Fin.ixcial Collupse of the Penn Central Compiny 86 (Subcomm. Print 1972). Overall losses have continucd throughout Penn Central's reorganization. Net losses were $\$ 189$ million in 1973 , and $\$ 198$ million in 1974. N.Y. Times, Feb. 20, 1975, at 43, col. 1 .

The bankruptcies of the Penn Central and other Northeastern carriers have stemmed from a number of causes: intense competition from trucking and air transport, a declinc in the industrial activity of the Northeast as a major source of freight demand, and imbalanced federal aid to transportation. The decline in railroads competitive position has been sclf-sustaining; operating deficits have led to undermaintenance of equipment and track, which in turn has increased operating expenses. See S. Rep. No. 93-601, supra note 2, at 6-14; Specine Study Group on Transp. Policies in the United Stitrs, Senite Comm. on Interstate and Foreign Commerce, 87th Cong., Ist Sess., Nation.lL Transportation Policy 67-81 (Comm. Print 1961); G. Hiltox, supra note 3, at 3-2l; Barber, supra note 3, at 553-67; Meycr \& Morton, The U.S. Railroad Industry in the Post-World War II Period: A Profile, 2 Exploritions in Economic Research 449, 450.68 (Nat'l Bur. Econ. Res. 1975).

12. This figure excludes various nonrail assets such as Penn Central's Park Avenuc properties in New York City. PCTC Physical Asset Valuation Study (Apr. 1973, revised May 30, 1973), ciled in In re Penn Cent. Transp. Co., 384 F. Supp. 895, 924 n.47 (Regional Rail Reorg. Spec. Ct. 1974). The study was commissioned by the Penn Central trustees.

Table I (following page) presents other cstimates of the liquidation value, book valuc, and net investment in transportation property of each of the seven railroads in Comrail.

13. USRA has predicted that net annual income applicable to Conrail common stock will become positive in 1980 and will reach $\$ 267$ million (in inflated dollars) by 1985 . I Fin,al SYstem Plan, supra note 10, at 51. Penn Central has challenged USRA's income figures. According to Penn Central, USRA's projections show post-interest income of $\$ 280$ million (in 1973 dollars) by 1985 , while Penn Central predicts only \$23 million. Sec Statement of the Penn Central Trustees on the United States Railway Association's Final System Plan, Sept. 16, 1975, App. at 6 (on file with Yale Law Journal). The difference, according to Penn Central, lies largely in USRA's projections of increased freight revenues. $I d$. at $2-4,6$.

Conrail's chances for profitable operation were apparently improved by the recent decision of the Chessie System not to purchase 2,000 miles of track held by the Erie Lackawanna, Rcading, and Penn Central railroads. The Chessie acquisition would have provided significant competition to Conrail in bidding for freight traffic. N.X. Times, Feb. 13, 1976, at 45, col. 8; Wall St. J., Feb. 13, 1976, at 2, col. 2. 


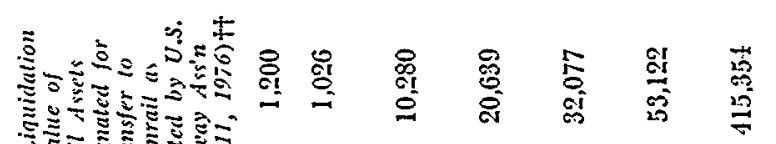

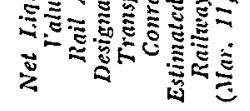

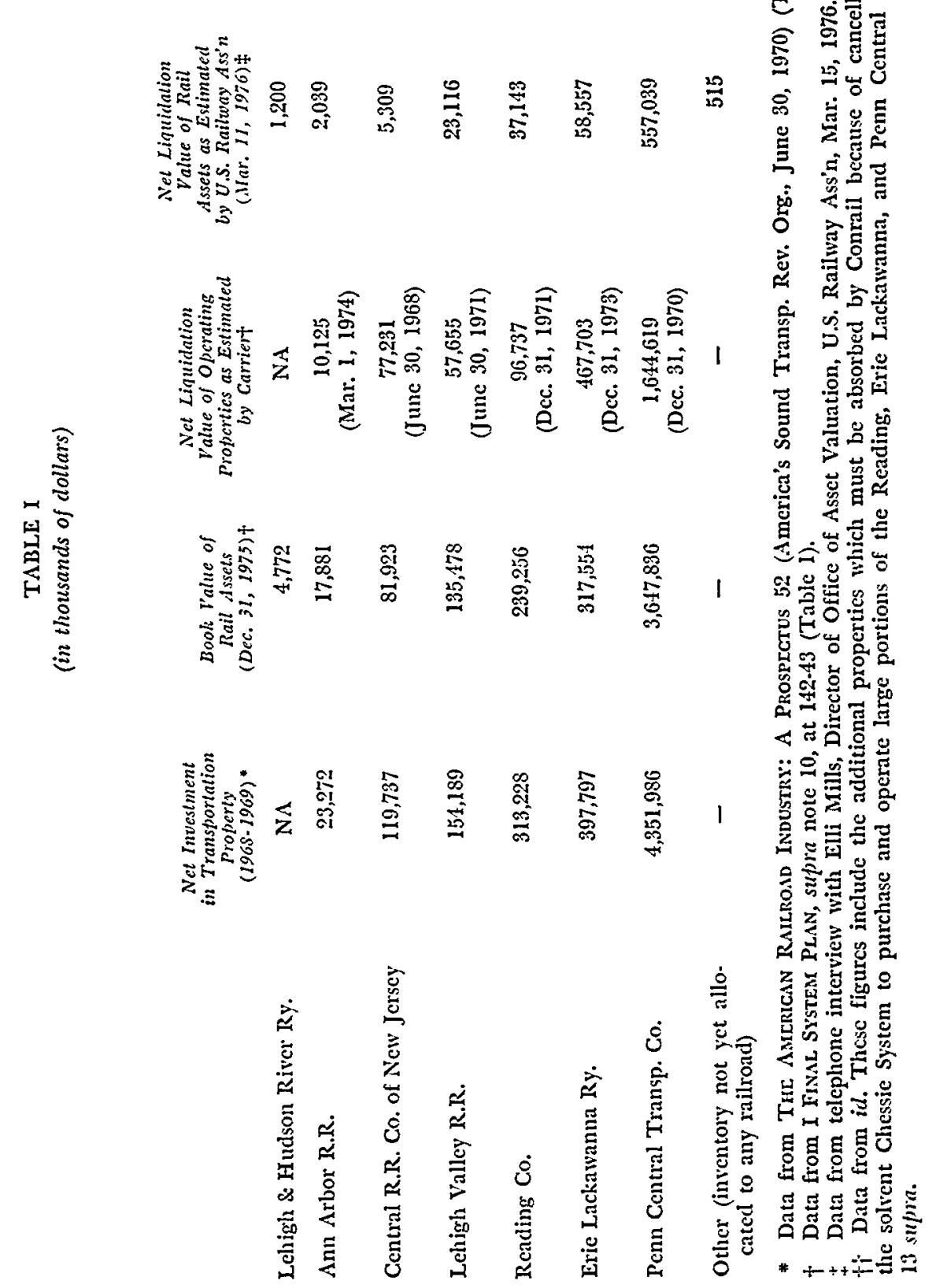




\section{A. The Claims: Erosion Taking and Conveyance Taking}

The assertion that creditors and stockholders of an insolvent railroad have a Fifth Amendment right to receive at least liquidation value in a reorganization has been raised in two forms. The first is the claim of "erosion taking"-that requiring deficit operations by the railroads pending inclusion in Conrail has unfairly reduced the portion of the estates available to satisfy creditors and stockholders in any eventual dissolution, ${ }^{14}$ thus constituting a taking of the amount eroded. The second concerns the compensation ultimately received for transferred assets. When the Conrail system becomes operative in early 1976 by a conveyance of various assets from the old railroads to Conrail, the debtors' estates of the railroads-and through them the old secured creditors, unsecured creditors, and stockholders ${ }^{15}$-will receive participations in the Conrail system in the form of preferred and common stock, ${ }^{16}$ underwritten by a $\$ 450$ million federal guarantee..$^{17}$ The railroads have argued that insofar as the value of the securities falls short of the liquidation value of the assets conveyed, the deficit will constitute a "conveyance taking." 18

\section{B. “Taking" as Shortfall in a Reorganization}

The creditors are certainly correct in asserting that the possibility of a taking is inherent in the Rail Act. This is so simply by virtue of the conclusion that creditors and stockholders of the bankrupt

14. Rail Act $\S 304(\mathrm{f}), 45$ U.S.C. $\S 744(\mathrm{f})$ (Supp. IV 1974), required that any railroad potentially included within Conrail maintain rail service pending completion of the Final System Plan unless USRA authorized the abandonment and "no affected State or local or regional transportation authority reasonably oppose[d] such action."

The erosion might have occurred through the accumulation of taxes and administrative expenses, both of which have priority over the claims of secured creditors; the issuance of trustee's certificates to raise cash for deficit operations, again with priority over creditors; and postponed maintenance. See In re Penn Cent. Transp. Co., 384 F. Supp. 895, 923-25 (Regional Rail Reorg. Spec. Ct. 1974); Regional Rail Reorganization Act Cases, 419 U.S. 102, 124 (1974).

15. Compensation for assets transferred to Conrail from insolvent railroads will bc paid directly to the trustees of the estates of the railroads, and subsequently be distributed to the creditors and stockholders having claims against or interests in the estates. Sce Rail Act $\$ 303(c)(4), 45$ U.S.C. $\$ 743$ (c)(4) (Supp. IV 1974).

16. Each estate is to be allocated shares of Conrail Series $B$ preferred stock on the basis of the net liquidation value of the assets it has transferred to Conrail. (The liquidation value is to be calculated as of the date of transfer.) In addition, cach cstatc will receive common stock based on its prospective contribution toward the "excess earnings" of Conrail-that is, projected earnings exceeding the amount necessary to service the Government's loans and the Series B preferred stock. I Final System Plan, supra note 10, at 137).

17. Id. at 135. These "Certificates of Value" can be reduced in amount if the constitutional minimum to which the rail estates are entitled should be less than the amount of the guarantees. $I d$. at 138 .

18. See briefs of the Penn Central and New Haven railroads cited in note 10 supra. 
railroads must have some minimum constitutional entitlement in the assets which constitute the estates of the railroads. The interim continuation of deficit operations and the transfer of the railroad assets to Conrail are mandatory steps ${ }^{19}$ completed before any determination of the value of Conrail's securities and other benefits."0

But the fact that some taking may occur should not short-circuit the puzzling question of when the taking arises, that is, the magnitude of creditors' and stockholders' entitlement in the Conrail reorganization. The possibility of a taking cannot lead to an easy conclusion that liquidation value is the entitlement, for the basic design of the Rail Act has been held to be an exercise of bankruptcy porver, not of eminent domain. ${ }^{21}$ Mandatory conveyance of rail properties to

19. Rail Act $\$ \$ 206(d)(1), 303(b)(1), 304(f), 45$ U.S.C. $\$ \$ 716(d)(1), 743(b)(1), 744(f)$ (Supp. IV 1974).

20. See id. $\$ 303(c)(1), 45$ U.S.C. $\$ 743$ (c)(1) (Supp. IV 1974).

21. [T] here is nothing in the Act fundamentally at odds with the expressed purpose of Congress to supplement the reorganization laws . . . and, with the Tucker Act, the Rail Act is valid as a reorganization statute.

Regional Rail Reorganization Act Cases, 419 U.S. 102, 150 (1974). This conclusion was reached in rejecting the claim of the rail estates that compensation had to be given in cash rather than in securities because the Rail Act was an eminent domain or condemnation statute. In the Court's view, Conrail was properly characterized as a method of reorganization despite the Rail Act's provisions for federal representation on Conrail's board of directors and for a compulsory conveyance of properties to Conrail that dispenses with the vote of creditors required in a $\$ 77$ proceeding. Ill. at 152-54.

Some aspects of this characterization are debatable. In holding that federal repsesentation on the Conrail board of directors is not sufficient to make Conrail a federal instrumentality, the Court noted that the federal appointees would serve only so long as federally guaranteed debentures constituted 50 percent or more of Conrail's indebtedness. Id. at 152. Yet it is the provision of federally guaranteed debt which allows the railroads to be regarded as reorganizable in the first place. In addition, onc might expect in practice that the eight federally appointed directors will not balance public and private interests in the same manner as would the seren privately elcctcd directors. Federal directors might, for instance, more vigorously support measures which defer immediate earnings in favor of reinvestment in improved service.

Still, the fiduciary responsibilities of federal directors toward the private sharcholders are in theory the same as those of private directors. And the federal govenment's in. terest in having some voice in the administration of its capital contribution is understandable in light of the heavy criticism of Penn Central's management and accounting practices in the period before bankruptcy. Nor was the phenomenon of some federil control over railroad management unknown in previous railroad reorganizatious under $\$ 77$. In the $1930^{\circ}$ s and $1940^{\circ}$ s, the Reconstruction Finance Corporation (RFC) functioned as a source of credit for ailing railroads both before and after insolvency. Typically, the credit of the railroad was so low that no new private money could be raised to refund RFC loans; the RFC was instead paid off in junior securities of the reorganizet railroat, and given some representation on the board of directors. As Dewing has notcd:

This situation was conspicuously true of . . the large, Class I roads. The government, through its instrumentality, the Reconstruction Finance Corporation, mut accept securities of the new road .... In consequence, ... the government became a partner in the enterprise and supplied one or more dircctors to the board of the reorganized road. ... [A]nd ... through the power of its loans was in a position to dominate the policy of the reorganized road.

II A. Dewing, supra note 3, at 1263 (footnotes omitted).

The Court does seem on solid ground in finding the mandatory character of the 
Conrail, as a corporation retaining substantial private character, does not constitute a condemnation of property by the Government. Nor does the fact that Conrail is being aided by federal loans and other measures serve to remove the proceeding from the frame of reorganization, or increase creditors' and stockholders' entitlement above that of a traditional reorganization."2

In a $\$ 77$ reorganization, the conveyance of rail assets to a reorganized corporation normally does not give rise to a taking, because the reorganization is supposed to go forward only when the securities distributed in exchange for those assets are of sufficient value to meet creditors' and stockholders' constitutional entitlement in a reorganiza-

conveyance insufficient to take the statute out of the bankruptcy power. Section 77 has traditionally provided for the confirmation of a reorganization plan over the protest of creditors holding up to one-third in amount of any class of securities and even, by use of the "cram-down" power, over the objection of a majority of any class, so long as the plan is "fair and equitable." Bankruptcy Act $\$ 77(\mathrm{e}), 11$ U.S.C. $\$ 205(c)$ (1970); Reconstruction Fin. Corp. v. Denver \& R.G.W.R.R., 328 U.S. 495, 531-33 (1946). In practice, a cram-down over the protest of a large dissenting vote of creditors might seem unlikely. See 14 U. CHI. L. Rev. 84, 91 (1946). But the occasion may not often have arisen because of the acceptance of the view that railroads are subject to reorganization if any plan is workable.

22. The Final System Plan calls for $\$ 1.85$ billion federal investment in Conrail between 1976 and 1981. I Fin.al Systex Plan, supra note 10, at 135. This amount may increase to $\$ 2.03$ billion because of the Chessie's withdrawal from purchase of trackage. Wall St. J., Feb. 13, 1976, at 2, col. 3. The first part of this funding was authorized carly in 1976. Id., Feb. 6, 1976, at 2, col. 3. This loan aid finds some analogy in the funding obtained in $\$ 77$ reorganizations from private Iending institutions, or in the 1930's and 1940's, from loan programs of the Reconstruction Finance Corporation. In addition, similar loan guarantees of up to $\$ 1$ billion for acquisition and rehabilitation of facilities are provided by 1976 legislation to all railroads in the nation. N.Y. Times, Feb. 5, 1976, at 45, col. 6. Recent legislation authorizing a \$1.6 billion direct grant for the rehabilitation of roadbed in the Boston-to-Washington corridor is intended mainly to aid the development of high speed passenger service by Amtrak and will have only incidental benefits for freight operations. $1 d$. at 45 , col. 5 .

Nor should the $\$ 450$ million federal guarantee of the value of Conrail preferred and common stock necessarily change the standard of entitlement-the rail estates can hardly complain that the hazard of predictions about future income is being assumed by the Government. Still, it is arguable that if at the time of the Special Court's estimate the projected earnings-based value of Conrail is less than the amount constitutionally required to sustain a reorganization, the rail estates should receive an amount close to liquidation value. (Were one to hold that the "reorganization minimum" could be met through payment in cash via a Tucker Act remedy, or in guaranteed Certificates of Value, then any line between valuation in reorganization and in condemnation would become confused. A property incapable of earning any net operating income at all would be "reorganizable.") For a similar view, see I Final System Plan, supra note 10, at 123 .

An alternative position is that where railroad properties are capable of earning any net operating income, creditors and stockholders should be entitled only to the constitutional minimum required for reorganization. The "taking" would consist only of the difference between the earnings-based going-concern value and the minimum necessary for reorganization, rather than the difference between earnings-based going-concern value and liquidation value. 
tion proceeding. ${ }^{23}$ Similarly, in the Conrail transfer, no taking will arise so long as the value of the Conrail securities is sufficient to meet creditors' and stockholders' constitutional entitlement in a railroad's estate in reorganization. ${ }^{24}$ (The estates of the bankrupt railroads have been remitted to a suit under the Tucker Act in the Court of Claims to make up for any shortfall in value. ${ }^{25}$ )

\section{The Brooks-Scanlon 'Right to Retrieve'}

The argument that liquidation value is the due of creditors and stockholders in a reorganization proceeding rests principally on an early line of cases which address the right to 'retrieve' property from 'unprofitable' uses.

The cases are three: Brooks-Scanlon v. Railroad Commission," Bullock v. Florida ex rel. Railroad Commission, ${ }^{27}$ and Railroad Commission v. Eastern Texas Railroad. ${ }^{28}$ While Brooks-Scanlon and Eastern Texas do involve the Supreme Court's approval of the abandonment of whole railroads against the opposition of state regulatory commissions, their import is subject to major qualification. Contrary to some commentators, ${ }^{29}$ the 'right to retrieve' of these cases does not establish liquidation value as creditors' invariable due. First, and most important, the railroads involved seem to have been hopelessly unprofitable, with no prospect of rehabilitation to a break-even point on either a private or publicly-assisted basis. They appear to have been operating at a loss not simply in the sense of having no income available for equity after payment of some charges for the use of capital, such as bond interest, but in having no net railway operating income ${ }^{30}$ at all. ${ }^{31}$

23. Under $\$ 77(\mathrm{e}), 11$ U.S.C. $\$ 205(\mathrm{e})(1970)$, the judge must find a plan to be "fair and equitable" before the plan can be confirmed. See Regional Rail Reorganization Act Cases, 419 U.S. 102, 154-55 (1974); id. at 183 (Douglas, J., dissenting).

24. Regional Rail Reorganization Act Cases, 419 U.S. 102, 155 (1974).

25. Id. at 136,148 .

26. 251 U.S. $396(1920)$.

27. 254 U.S. 513 (1921).

28. 264 U.S. 79 (1924).

29. Comment, supra note 10, at 514; Note, supra note 10, at 1008-10, $1018,1020$.

30. Net operating income is calculated before any charges are made for the use of capital, such as interest on debt and leased line rentals. However, it does include payments on equipment leases. See In re Penn Cent. Transp. Co., 384 F. Supp. 895, 925 (Regional Rail Reorg. Spec. Ct. 1974); ICC, 87th Annual Report on Transport Statistics in the United States 50 (Table 156(D)), $56-59$ (Table 161) (1973).

31. In Brooks-Scanlon, the railroad was said to be unable to run "except at a loss of more than $\$ 1500$ a month." Brooks-Scanlon Co. v. Railroad Comm'n, 251 U.S. 396. 397 (1920). Neither the Brooks-Scanion Company nor its subsidiary, the Kentwood and Eastern Railway Company, which actually operated the road, appears to have had any bondholders. 144 La. 1086, 1090-91, 81 So. 727, 728-29 (1919). Hence the loss was independent of debt service or other return on capital. Although the Kentwood Company 
That a railroad's investors cannot be required to keep up operations at an out-of-pocket loss where rehabilitation has been shown to be impossible does not establish a right to retrieve their capital if, by consolidating some operations and abandoning others, a relatively profitable operation can be effected. ${ }^{32}$

Second, in Bullock and Eastern Texas there was no prior legislation supporting a duty to continue rail operations for a period of time despite losses, ${ }^{33}$ an omission which Justice Holmes seems to have found

leased the railroad from its parent Brooks-Scanlon Company and thus was obligated as a short term expense for the amount of the lcase, the road seems clearly to have been rumning at a loss even before the lease payment.

The plaintiff [Brooks-Scanlon Company] may be making money from its sawmill and lumber business but it no more can be compelled to spend that than it can be compelled to spend any other money to maintain a railroad for the benefit of others who do not care to pay for it.

251 LY.S. at 399 (cmphasis added).

In Bullock, the Ocklawaha Valley Railroad was in default on its mortgage bonds. A state court found that it "could not be operated so as to have any net income whatever," Bullock v. Florida ex rel. Railroad Comm'n, 254 U.S. 513, 519 (1921), but it is not clear whether this meant before or after debt service. The foreclosure decree in dispute, issued by a lower Florida court, did not recognize an unburdened right to liquidation valuc; it required that the road first be offered for sale as a common carrier. Only if all bids for use as a common carrier were under $\$ 200,000$ could the railroad be offered for sale with the privilege of dismantling, and a bid for dismantling could not be accepted unless at least $\$ 100,000$ over the bids for use as a common carrier. Id. at 520 . Thus if scrap value of the railroad was $\$ 300,000$, the bondholders' estatc could be deprived of up to one-third its value before any objectionable burden was found by the state court. If the scrap value was $\$ 100,000$, the bondholders could be deprived of over 99 percent of its value-in the interest of selling the railroad as a going concern. There was in fact no bid for the railroad as a going concern, State ex rel. Railroad Comm'rs v. Bullock, 78 Fla. 321, 324, 82 So. $\$ 66$, 866.67 (1919), suggesting that it had no net operating income whatever, even before hypothetical debt service.

In Eastern Texas, the railroad's property

was offered for sale at $\$ 50,000$ to any one who would operate the road, and the offer was widely advertised, but without eliciting any acceptance or bid. Essential repairs would cost $\$ 185,000$. The operating cost would be as much as $\$ 84,000$ per year; the possible revenue from all traffic would not exceed $\$ 50,000 \ldots$.

Railroad Comm'n v. Eastern Tex. R.R., 264 U.S. 79, 83 (1924). The Eastern Texas Railioad did not have any mortgage debt issued against its property or other debt; hence its "operating loss" was exclusive of debt service. Texas v. Eastern Tex. R.R., 283 F. 584, 588 (W.D. Tex. 1922).

32. The right to retrieve recognized by Justice Holmes was qualified accordingly. A past history of losses was not sufficient to establish a constitutional right to abandon. There also had to be "no reasonable prospect of profitable operation in the future." Bullock v. Florida ex rel. Railroad Comm'n, 254 U.S. 513, 521 (1921). See also Justice Van Devanter's formulation in Railroad Comm'n v. Eastern Tex. R.R., 264 U.S. 79, 85 (1924) ("II]f at any time it develops with reasonable certainty that future operation must be at a loss, the company may discontinue operation ....") (emphasis added).

33. See Bullock v. Florida ex rel. Railroad Comm'n, 254 U.S. 513, 520 (1921) ("The decision of the [state] Court proceeds upon a doctrine as to the duty of the railroad company, again a duty not based upon statute . . . ."); Railroad Comm'n v. Eastern Tex. R.R., 264 U.S. 79, 87-89 (1924) (statutory provisions relied on by the railroad commission did not specify any duty of railroad to continue operations).

In Brooks-Scanlon, the state supreme court decided that the carrier was not running at a loss if one lumped together the Brooks-Scanlon Company's railroad and nonrailroad business; the Supreme Court reversed on the ground that such aggregation was improper. 
significant. ${ }^{3 *}$ In the early regulation of railroads, states often relied on franchise grants to impose quasi-contractual obligations of continued service.: ${ }^{: 5}$ As the practice of special legislative grants of charters and franchises was superseded by general acts of incorporation, state regulation of railroad abandonments was also placed in the exercise of police powers over natural monopolies. ${ }^{30}$ And from 1920 on, federal power to regulate interstate commerce has been used to limit the abandonment of railroads in interstate commerce, under $\$ 1(18)$ of the Interstate Commerce Act. ${ }^{37}$

Third, though one must administer legal realism warily, it should be noted that the railroads in the 'right of retrieval' case law were relatively small logging roads whose situation was staggeringly dissimilar to Penn Central's position in the Northeastern economy.3.

As an alternative, the state court might have reasoned that the railroad, though unprofitable, operated under a statute allowing the railroad commission to require service at a loss for some reasonable period of time. The Louisiana Railroad Commission wat empowered under the state constitution to "regulate . . . tariffs and service.....", LA. Const. art. 284 (1913), readopting id. (1898), and this provision had been held sufficient to allow the Commission to prohibit the abandonment of track. Railroad Comm'n v. Kansas City S. Ry., 111 La. 133, 138, 35 So. 487, 489 (1903). But the Supreme Court could then have replied that authority to restrict abandonment had to be delegated expressly.

34. Apart from statute or express contract people who have put their money into a railroad are not bound to go on with it at a loss if there is no reasonable prospect of profitable operation in the future. ...

... Without previous statute or contract to compel the company to keep on at a loss would be an unconstitutional taking of its property.

Bullock v. Florida ex rel. Railroad Comm'n, 254 U.S. 513, 520-21 (1921) (emphasis added).

35. See the typical reasoning of the state court in Gates v. Boston \& N.X.A.L.R.R., 53 Conn. 333, 5 A. 695 (1885), appeal dismissed, 122 U.S. 646 (1887), a case in which counsel Simeon E. Baldwin defended the right of the state to provide for reorganization of a railroad over the protest of individual bondholders.

It is true that the charter is permissive in its terms, and probably no obligation rests upon the corporation to construct the railroad ... . [But] by so accepting and acting upon the chartered powers a contract exists to carry into full effect the objects of the charter, and the capital stock, franchises and property of the corporation stand charged primarily with this trust. . . Having exercised those powers the corporation has no right against the will of the state to abandon the enterprise, tear up its track, and sell its rolling-stock and other property, and divide the proceeds among the stockholders.

53 Conn. at 342-43, 5 A. at 699. See C. Cherington, The Regulation of Railroad AbinDONMENTS 18-20 (1948); Field, The Withdrawal from Service of Public Utility Companies, 35 YALE L.J. 169, 172 (1925).

36. See, e.g., C. Cherington, supra note 35, at 22 \& n.22, 24 \& n.27; Ficld, supra noto 35 , at $170 \mathrm{n.4}$.

37. See note 74 infra.

38. It may be that how far noncompensable regulation can properly diminish the value of property should depend on the seriousness of the public problem-be it nuisance or economic disruption-which the regulation is sceking to avoid. In an abandonment of the mammoth Penn Central rail network, the economic loss caused to railroad users and the economy would be disproportionately larger (compared to the loss to bondIolders and stockholders from continued operation) than in the liquidation of a small railroad which has few linkages with other parts of the economy.

Professor Michelman is generally critical of this type of "balancing" to determine the 
The Brooks-Scanlon railroad was "primarily a logging road" doing a "small business as a common carrier" and had actually shut down and sold off all its rolling stock two years before the case reached the Supreme Court. ${ }^{39}$ Eastern Texas involved a 30-mile logging road running through a "sparsely populated" area, and serving a lumber industry that had long since "exhausted the adjacent supply of timber" and closed down. ${ }^{40}$ The road had run unprofitably for seven years by the time the Supreme Court heard the case, and its withdrawal from interstate and foreign commerce already had been approved by the Interstate Commerce Commission. ${ }^{41}$ Bullock also involved a logging road. ${ }^{42}$

In addition, one might approach the two Holmes opinions, BrooksScanlon and Bullock, with the cautioned view suggested by the late Professor Bickel in his discussion of Brandeis's role in forming the Bullock opinion. Holmes's broad declarations of the rights of property sometimes concealed conditions and left premises unstated. ${ }^{43}$

\section{Preserving the Value of Creditors' Liens}

The second line of case law which bears on the entitlement of creditors and stockholders is that upholding the constitutionality of

limits of noncompensable regulation. Michelman, Property, Ulility, and Fairness: Comments on the Ethical Foundations of "Just Compensation" Law, 80 HARv. L. REv. 1165, $1194-96$ (1967). But in the case of interstate railroads, Michelman's emphasis on the importance of expectations (id. at 1239, 1240) lends balancing a greater legitimacy, for the federal statute constraining railroad abandonments itself explicitly uses a balancing between losses to the railroad and losses to rail users. See p. 392 infra. See also Michelman, supra at 1191 n.53, 1234-35.

39. 251 U.S. at 398 . A court may understandably be more amenable to prohibiting abandonment than requiring reassemblage of rail operations, especially for an admittedly experimental period of operations. See Field, supra note 35, at 185 (in period before state commission regulation, specific performance considered an improper form of relief where utility had already dismantled plant).

40. 264 U.S. at 83 .

41. Texas v. Eastern Tex. R.R., 258 U.S. 204, 214, 215 (1922).

42. 254 U.S. at 519.

43. Not infrequently Holmes' "forms of words," as he liked to call them, seemed more sweeping than he really intended them to be, or than-refusing to descend from the eminence of subtle silent premises and reservations on which he was poised-he could be made to see that they would seem.

A. Bickel, The Unpublished Opinions of Mr. Justice Brindeis 226 (1957). Justices Brandeis and John Clarke apparently took a skeptical view of the Bullock opinion. As Bickel notes, Brandeis took the view that a constitutional right to discontinue operations could not be given effect as a gencral proposition, because its existence had to depend on varying particular circumstances, of which the state should be the judge.

Id. at 231. Clarke signed the Bullock opinion, but was disturbed by its unyielding tone: "I fear . . . that, in its present form, [the opinion] may be seized upon as a justification for taking up temporarily unprofitable branch lines to the great inconvenience and loss of many communities."

Id. at 236, citing Holmes Papers, Library of Harvard Law School. 
traditional $\S 77$ rail reorganizations. There are striking statements in these cases that the reorganization practices complained of were justifiable because they affected only the remedial rights of creditors and did not alter the value of their liens. ${ }^{44}$

But there also has been continuing acceptance by the Court of suspensions of mere "remedy" which may result in real financial loss. The Court has acknowledged that during suspension of foreclosure rights the value of the collateral sometimes will decline. ${ }^{45}$ Long delays are often incurred in attempting to work out reorganization plans under $\$ 77,46$ and on at least one occasion this has placed a heavy burden on the estate of a railroad: in the New Haven bankruptcy, the Supreme Court approved the imposition on New Haven bondholders of more than six years of erosion loss as part of the railroad's reorganization and inclusion within the merged Penn Central

44. In Continental Ill. Nat'l Bank \& Trust Co. v. Chicago, R.I. \& Pac. Ry., 294 U.S. 64S (1935), the first major Supreme Court decision concerning $\$ 77$, the reorganization court had issued an injunction against the sale of mortgage bonds pledged as collateral for certain notes. The Court upheld the injunction on grounds that release of the bonds would have made impossible the formulation of a reorganization plan. Id. at 678. As assurance that the seniors were not denied due process by the suspension of their contractual right of sale as pledgee, the Supreme Court noted: "The injunction here goes no further than to delay the enforcement of the contract. It affects only the remedy." $I d$. at 681 . In Reconstruction Fin. Corp. v. Denver \& R.G.W.R.R., 328 U.S. 495 (1946), the Court upheld the confirmation of a reorganization plan over the objection of the junior general mortgage bondholders, with language that also distinguishes between impairment and suspension of a lien:

[The bankruptcy powers of Congress] are adequate to require creditors to acquicsce

in a fair adjustment of their claims, so long as the creditor gets all the value of

his lien and his share of any free assets.

Id. at 533 (footnote omitted) (cmphasis added), ciled in Rcgional Rail Rcorganization Act Cases, 419 U.S. 102, 153, 154-55 (1974).

45. Continental IIl. Nat'I Bank \& Trust Co. v. Chicago, R.I. \& Pac. Ry., 294 U.S. 61s, 677 (1935). See New Haven Inclusion Cases, 399 U.S. 392, 490-93 (1970).

46. The reorganization of the Western Pacific Railroad took $71 / 2$ years (\$ 77 petition filed August 2, 1935; plan certified by the ICC September 28, 1939, with an effective date of January 1, 1939; confirmed by district court August 15, 1940; upheld by Supreme Court March 15, 1943). Ecker v. Western Pac. R.R., 318 U.S. 448, 453, 509 (1943); In re Western Pac. R.R., 34 F. Supp. 493, 506 (N.D. Cal. 1940). The reorganization of the Denver Rio Grande Railroad lasted 101/2 years (\$ 77 petition filed Norember 1, 1935; final plan certified by the ICC June 14, 1943, with an effective date of January 1, 1943; plan confirmed by district court Norember 29, 1944; upheld by Supreme Court June 10, 1946). Reconstruction Fin. Corp. v. Denver \& R.G.W.R.R., 328 U.S. 495, 500-01, 521 (1946). The Chicago, Rock Island \& Pacific Railway reorganization lasted 15 ycars ( $\$ 77$ petition filed June 7, 1933; plan certified by the ICC May 1, 1944; plan confirmed for the final time by the district court Junc 26, 1947; plan upheld by court of appeals June 2, 1948). In re Chicago, R.I. \& Pac. Ry., 168 F.2d 587, 589, 592 (7th Cir.), cert. denied sub nom. Texas v. Brown, 335 U.S. 855 (1948). Sec Kalmbach, The Rcdedication of Lightly $U$ sed or Abandoned Rail Rights of Way to Other Uses, 7 TR.Nsp. L.J. 99, 128 (1975) (Missouri Pacific reorganization lasted 23 years; Florida East Coast, 20 years; St. Louis-San Francisco, 14 years). 
system. Between $\$ 60$ and $\$ 70$ million was lost from the pre-bankruptcy liquidation value of the New Haven's assets. ${ }^{47}$

In addition, the securities paid to secured creditors in $\$ 77$ reorganizations frequently have been assigned a value higher than any ever attained in the market. Though senior creditors are in theory compensated for the liquidation value of their liens, some fare less well

47. New Haven Inclusion Cases, 399 U.S. 392, 490-93 \& n.82 (1970). The New Haven reorganization began on July 7,1961 , and has lasted until the present time. For a useful summary of the proceedings until early 1973, see In re New York, N.H. \& H.R.R., 479 F.2d 8, 9-13 (2d Cir. 1973). The original expectation was that transfer of the New Haven's assets to the merged Penn Central system would effectively conclude the New Haven's reorganization. But the bankruptcy of the Penn Central in 1970, only 21/2 years after the approval of its merger, and the collapse in value of the Penn Central stock received by the New Haven as compensation, effectively tied the fate of the New Haven creditors to the Penn Central reorganization.

The price to be paid by Penn Central to New Haven bondholders was the liquidation value of the New Haven's properties as of December 31, 1966. New Haven Inclusion Cases, 399 U.S. 392, 489 (1970). Thus, the burden of five ycars' crosion was placed on the bondholders. In addition, losses from continued deficit operations between 1967 and the effective date of the Penn Central merger, January 15, 1968, were borne solely by the New Haven's bondholders, itl. at 493, as well as one-third of the operating losses from the date of the merger until actual inclusion of the New Haven in the merged system 11 months later. Id. at 479 . The Court held the burden was constitutional, for the bondholders had

"invested their capital in a public utility that does owe an obligation to the public. . . [B]y their entry into a railroad enterprise, [they] assumed the risk that in any depression or any reorganization the interests of the public would be considered as well as theirs."

Id. at 491-92, quoting Reconstruction Fin. Corp. v. Denver \& R.G.W.R.R., 328 U.S. 495, 535-36 (1946). The crosion may have been as much as 28 percent of the pre-bankruptcy value of the New Haven's estate. See Notc, supra note I0, at 1007 n.19.

Most of this erosion was incurred when it was already apparent that an independent income-based reorganization of the New Haven was impossible. See In re New York, N.H. \& H.R.R., 479 F.2d 8, 10 (2d Cir. 1973) ("Since the previous decade had demonstrated convincingly that the New Haven's traffic patterns could not gencrate sufficient revenues to meet its costs, no serious consideration was ever given to a reorganization plan that left the New Haven as an independent operating enterprise.") Thus, the erosion suffered by the railroads pending inclusion in Conrail is not disallowable merely because independent reorganization of those railroads has been impossible.

The 1966 liquidation value was paid in accord with the "fair and equitable" standard of $\$ 77$. See 399 U.S. at $489-90$. The Court expressly declined to decide whether payment by Penn Central to the New Haven of an amount lower than the 1966 liquidation value would have constituted a taking. $I d$. at 490 . Howerer, the Court did approve the reorganization court's vigorous rejection of an ICC proposal to reduce by another $\$ 28$ million the compensation paid by Penn Central to New Haven's creditors. Id. at 45I76. Though the rebuff of the ICC was based on nonconstitutional grounds, it might suggest that the Court would have found any lesser amount to be a taking. Still, the Cour's approval of placing large post-1966 losses on the estate of New Haven, sul)ordinating bondholders' claims even further, suggests that the 1966 liquidation valuc could be a constitutional minimum only in some limited sense-perhaps the minimum payable by an acquiring railroad for assets, which procecds can be further invaded because of the payee's service obligation.

For the suggestion that the opcrating erosion was approaching its constitutional limit. see In re New York, N.H. \& H.R.R., 289 F. Supp. 451, 459 (D. Conn. 1968) (continued erosion of New Haven's cstate from operating losses beyond the end of 1968 would constitute a taking). 
than they would have in an immediate liquidation. ${ }^{48}$ Junior creditors may be better off as a result, but that does not change the character of the invasion of the seniors' security, if it is indeed an anticipatable $e^{10}$ invasion of liquidation value which gives rise to a taking. Though the Special Court's estimate of the going-concern value of Conrail securities could be subject to the same disparity, the federal guarantee of the value of Conrail Series B preferred and common stock will eliminate much of the risk of overestimation. ${ }^{50}$

48. This is, of course, the basis for perennial conflict between the seniors and juniors of a business. If going-concern value appears greater than liquidation value, seniors will be asked to forego the immediate cash satisfaction of their matured claims in favor of continuing the business to allow juniors a chance of compensation. The full compensation for seniors required under absolute priority is rarely met because priovitien are observed with securities whose face value, rather than market value, cquals the full amount of the claim. The securities received by seniors generally do not sell at their assigned value immediately, and frequently never do. See V. BrudNcy \& M. Chirelstein, Cases and Materials on Corporate Finavce 138-48 (1972); Brudncy, The Inveslment-Value Doctrine and Corporate Readjustments, 72 HARv. L. REv. 645, 673-75 (1959); Friendly \& Tondel, The Relative Treatment of Securities in Railroad Reorganization, Under Section 77, 7 LAw \& Contrmp. Proz. 420, 423-24 (1940). If the securities arsigned to seniors in the new company are of a subordinate rank assigned as well to the former juniors, then seniors must be awarded some additional value to make up for the loss of priority. Consolidated Rock Prods. Co. v. Du Bois, 312 U.S. 510, 529 (1911). But this bonus is frequently insufficient to give the old seniors the full value of their matured claims if the earnings of the reorganized company are not as high as expected.

49. [T]o the extent that reorganization plans approved by administrative agen-

cies and courts over a period of years embody almost consistent overestimale of

the expected value of the payout, and therefore almost consistent underpayment of the claim, the question may fairly be asked whether such an approach to the determination of the expected value of the package of new securitics reflects actual disagreement as to the target.

V. Brudney \& M. Chirelsteln, supra note 48 , at $144-45$ (emphasis added). See Brudney, supra note 48 , at 673 (overvaluation by the ICC has been "not entirely accidental").

50. The redemption value of the guarantee certificates will increase from $\$ 450$ million at the end of 1976 to $\$ 1,050$ million in 1987. I Final Systra PLAN, supra note 10, at 135. At the end of the 11 year period the guarantees will be sufficient to cover almost half of the net liquidation value of all the operating properties of the insolvent carriers, even according to the railroads' own estimates of net liquidation value. If one takes USRA's lower $\$ 534$ million estimate of the net liquidation value of properties designated for transfer to Conrail, the guarantees will be sufficient to cover the value within three years. The usual standard for valuing securities in a $\$ 77$ reorganization does not require that they have an immediate market value equivalent to their assigned value. Rather the securities need only have a "reasonable prospect" of selling at that value. See Missouri Pac. R.R., 290 I.C.C. 477, 555 (1954), plan approved, 129 F. Supp. 392 (E.D. Mo.), aff'd sub nom. Missouri Pac. R.R. v. Thompson, 225 F.2d 761 (8th Cir. 1955), cert. denied, 350 U.S. 959 (1956).

Even if one adheres to the strict requirement, described in note 22 supra, that any reorganization minimum below liquidation value be satisfied with earnings-based value, the federal guarantees can properly be used to argue that the constitutional minimum in Conrail should be lower than the estimated going-concern values of previous reorganizations. The "risk" in previous reorganizations was of two kinds: (a) anticipated risk, reflected in the estimated range of earnings and thus in the estimate of going-concern value; and (b) unanticipated risk, that is, risk omitted from the entimatc of the possible range of earnings. It is the latter which must account for the unusually frequent failure to realize projected going-concern values in $\$ 77$ reorganizations. Insofar as this underestimation of risk was deliberate, one expects the candor of the Special Court to provide a safeguard against recurrence. Only insofar as previous underestimation 
Finally, the "substantive value" of a creditor's lien or of a stockholder's equity has meaning only with reference to any independent rules which govern the use of the underlying property. As will be seen, ${ }^{51}$ there is such a rule operative in railroad mortgages-the statutory regulation of railroad abandonments which has empowered the ICC to prohibit any complete cessation of rail service or dismantling of rail lines until it is shown that the service is unavoidably unprofitable system-wide. This obligation-in a sense a covenant which runs with the railroad property-sharply distinguishes the reorganization of a rail carrier from the reorganization of a business not subject to regulation as a public utility. A farmer is free at any time to lay down his tools and sell his farm. The substantive value of a lien on his property has direct reference to the liquidation value of the farm. ${ }^{2}$ In contrast, the creditors of an insolvent railroad company are constrained by the same restrictions on abandonment of service which obligated the debtor railroad itself.

\section{Liquidation Value and $\S 77$}

The claim of a right to liquidation value in railroad reorganization may derive its greatest plausibility from the parallel history of the older reorganization statute governing all railroads in interstate commerce, $\$ 77$, and the reorganization statute governing industrial corporations, Chapter $\mathrm{X},{ }^{53}$ originally $\S 77 \mathrm{~B} .{ }^{54}$ The temptation is to view interstate railroad reorganization as simply another bankruptcy procedure, enacted to serve the best economic interests of junior creditors and stockholders by allowing the realization of going-concern value otherwise lost in the dismantling of an insolvent business. But $\S 77-$ though a statute using the bankruptcy power to extinguish valueless debt obligations-may also be viewed as an exercise of interstate commerce power over railroad operations.

\section{A. The Interstate Commerce Commission as a Party to Bankruptcy Reorganization}

The intertwining of the commerce and bankruptcy powers in the regulation of railroads can be seen, in a very mechanical way, in the

was unavoidable does the federal guarantee provide an extra benefit to creditors and stockholders participating in Conrail. But by definition, in reaching an estimate of Conrail's going-concern value for comparison with an earnings-based minimum, the Special Court can only take anticipatable risk into account; thus the federal guarantees would not affect the outcome of the test.

51. See pp. $391-94$ infra.

52. See Louisville Joint Stock Land Bank v. Radford, 295 U.S. 555 (1935).

53. 11 U.S.C. $\$ \$ 50 \mathrm{I}-676(1970)$.

54. See 11 U.S.C. $\$ 207$ (1970). 
structure of previous reorganization machinery. Since 1920 , a rail corporation has needed ICC approval in order to issue securities, ${ }^{55}$ so that even under equity receiverships the Interstate Commerce Commission assumed a role in structuring reorganized companies. ${ }^{50}$ Under $\S 77$, the ICG has had sole authority to certify a plan of reorganization to the supervising court; the plan may be different from any preferred by the private parties involved. ${ }^{57}$ The reorganization court can reject but cannot amend the plan and thus is left only with the possibility of a remand to the ICG. ss In a Chapter $\mathrm{X}$ reorganization, the Securities and Exchange Commission plays a much weaker role. Only if the company's debts exceed $\$ 3$ million must the reorganization court submit a plan of reorganization to the SEC for comment. ${ }^{59}$ And even then the SEC's views are merely advisory; the court can accept a plan prepared by one of the private parties whether or not the SEC. approves the plan. ${ }^{60}$

Under $\$ 77$, it is also the ICC that takes major responsibility for valuing the debtor, deciding what sort of securities structure the earnings can sustain. ${ }^{61}$ Judicial review of the ICC estimate traditionally has been limited.62 In Chapter $\mathrm{X}$, valuation is instead the responsibility of the reorganization trustee. ${ }^{63}$

\section{B. "Earning Power" and Section 77}

"Earning power" is mandated by $\$ 77$ as the primary criterion for valuation. ${ }^{64}$ There is no procedure requiring a comparison of the

55. 49 U.S.C. $\$ 20 a(2)(1970)$ (enacted by the Transportation Act of Feb. 28, 1920, ch. $91, \S 439,41$ Stat. $494-95)$.

56. However, this ICG supervision was not terribly effective, as "[t] $]$ he Commission's control was brought to bear so late in the proceedings that it usually gave its reluctant approval to unsound capital structures in order to avoid the costs of prolonged receivership." Fuller, supra note 3 , at 384.

57. Bankruptcy Act $\$ 77($ d), 11 U.S.C. $\$ 205(d)$ (1970). The independent trustec chosen by the reorganization court to continue running the business and to take primary re. sponsibility for an initial plan of reorganization can be appointed only with ICC. approval. Id. $\$ 77(c)(1)$, 11 U.S.C. \$ 205(c)(1) (1970). Under Chapter X, the SEC takes no part in the appointment of the trustee. See 11 U.S.C. $\$ 556(1970)$.

58. Bankruptcy Act $\$ 77(\mathrm{e}), 11$ U.S.C. $\$ 205(\mathrm{e})(1970)$.

59. 11 U.S.C. $\$ 572$ (1970); R. Jennings \& H. Marsh, Securitils Regulation 49 (1972).

60. 11 U.S.C. $\$ 572(1970)$.

61. Bankruptcy Act $\$ 77(\mathrm{e})$, 11 U.S.C. $\$ 205(\mathrm{e})$ (1970) ("If it shall be necessary to determine the value of any property for any purpose under this section [providing for acceptance of a reorganization plan by creditors and stockholders and confirmation of a plan by the court], the Commission shall determine such value and certify the same to the court in its report on the plan.")

62. Ecker v. Western Pac. R.R., 318 U.S. 448, 472, 474, 512 (1943). But see New Haven Inclusion Cases, 399 U.S. 392, 433-34 (1970).

63. 11 U.S.C. $\$ 567(5)(1970)$.

64. Bankruptcy Act $\$ 77$ (c), 11 U.S.C. $\$ 205$ (c) (1970); Group of Institutional Investors v. Chicago, M. St. P. \& Pac. R.R., 318 U.S. 523, 539-41 (1943). 
liquidation value and going-concern value of the rail assets. The ICC's failure to make an explicit comparison ${ }^{65}$ raises the suspicion that at times liquidation value may have been higher. In the leading: Supreme Court cases sustaining $\S 77$ reorganization plans and procedures, ${ }^{013}$ there has been no stated assumption that going-concern value exceeded liquidation value.

One may be tempted to object that $\S 77$ proceedings would only have been started when it was clear that going-concern value would probably exceed liquidation value. But in practice the initiation of reorganization proceedings would have been almost inevitable. Initiation of $\$ 77$ is available either by petition of the debtor or by petition of creditors with five percent or more of the aggregate indebtedness. ${ }^{67}$ Unless the liquidation value of an insolvent railroad was so high as to leave significant value for stockholders, it would be to their advantage to petition for reorganization in the hope that during the possibly lengthy proceedings, earnings prospects would improve sufficiently to leave them some participation in the new company. ${ }^{68}$ Once a $\$ 77$ proceeding is initiated, it cannot be unilaterally terminated by the debtor or creditors. Though any plan approved by the ICC is submitted to the creditors and stockholders for a two-thirds vote by class, ${ }^{69}$

65. See King, Feasibility in Chapter $X$ Reorganizalions, 49 AM. BANkr. L.J. 323, 337 n.17 (1975):

The SEC and the ICC appear to have different valuation approaches .... In Chapter X, the SEC estimates the future earnings and life expectancy of the enterprise as a whole, determines the appropriate capitalization rate, and then computes the value of the reorganized firm. The ICC, in section 77 proceedings, also starts with an estimate of the enterprise's total expected earnings, always taking the stream of earnings in perpetuity, but does not explicitly choose a single capitalization rate, nor does it reveal a final figure for reorganization value. The ICC only calculates "how large a capitalization can be supported by the predicted earnings."

66. Reconstruction Fin. Corp. v. Denver \& R.G.W.R.R., 328 U.S. 495 (1946); Group of Institutional Investors v. Chicago, M. St. P. \& Pac. R.R., 318 U.S. 523 (1943); Ecker v. Western Pac. R.R., 318 U.S. 448 (1943); Continental Ill. Nat'l Bank \& Trust Co. v. Chicago, R.I. \& Pac. Ry., 294 U.S. 648 (1935).

67. Bankruptcy Act $\$ 77(a), 11$ U.S.C. $\$ 205(a)$ (1970).

68. See W. Blum \& S. Kaplan, Materials on Reorganization, Recapitalizition AND INSOLVENCY 533-34 (1969).

69. Bankruptcy Act $\S 77(\mathrm{c})$, 11 U.S.C. $\$ 205(\mathrm{c})$ (1970). If the claims of a class of creditors or stockholders have "no value," the class need not be permitted to vote. Id. For voting purposes, the value of a class's interest is apparently determined according to whether there is room for its participation in the reorganization plan of the debtor. Sec Ecker v. Western Pac. R.R., 318 U.S. 448, 479 (1943) ("TT] he requirement of [judicial] affirmation of the exclusion of claimants [from voting] does not require an independent appraisal of the valuation which ordained their elimination. The court properly affirms the Commission, when it finds no legal objection to the Commission's use of its own valuation to determine whether particular claimants are entitled to participate in the rcorganization.") If a reorganization plan were formulated and approved by the ICC in circumstances where going-concern valuc happened to be less than liquidation 
the plan can be confirmed over any voting class's opposition under the "cramdown" poweri" so long as the judge finds the plan to be "fair and equitable."'t1

The plausibility of the claim that going-concern value always has been greater than liquidation value in $\$ 77$ proceedings is further undercut by the limited statutory alternatives hitherto available to an insolvent railroad. Railroads were excluded from all federal bankruptcy legislation until the passage of $\S 77$ because of the assumption that straight bankruptcy-aimed only at liquidation of assets with distribution of their proceeds to creditors and discharge of the debtorwas unsuitable for railroads obligated to continue service. Section 77 is strictly a reorganization statute, to rehabilitate the financial structure of the debtor. ${ }^{72}$ Even now there is no provision allowing a railroad to enter straight bankruptcy. ${ }^{73}$ The only course open to an insolvent interstate railroad that preferred to liquidate rather than reorganize would have been to enter an equity receivership and petition the ICC for permission to abandon service.

value, it thus appears that the junior classes most severely prejudiced by the reorganization would not be entitled to take part in one of the main devices provided under the Bankruptcy Act for signaling disagreement.

70. Bankruptcy Act $\$ 77($ e), 11 U.S.C. $\$ 205$ (c) (1970). See note 21 supra.

71. Bankruptcy Act $\$ 77(\mathrm{e}), 11$ U.S.C. $\$ 205(\mathrm{e})$ (1970). The "fair and equitable" standard has been used in $\$ 77$ as a term of art embodying the absolute priority rule, determining the order of creditors' claims. See Ecker v. Western Pac. R.R., 318 U.S. 448, 513 (1943) (Roberts, J., concurring); Case v. Los Angeles Lumber Prods. Co., 308 U.S. 106, 118 (1939). In the purchase of the New Haven's assets by the Penn Central system, "fair and equitable" was also the standard used in requiring payment by Penn Central of the 1966 liquidation value of the assets. See note 47 supra. But this approach to valuation was accepted where the railroad had "neither earning power nor the prospect of earning power." New Haven Inclusion Cases, 399 U.S. 392, 436 (1970).

72. As Justice Sutherland observed:

Section 77 adrances another step in the direction of liberalizing the law on the subject of bankruptcies. Railway corporations had been definitely excluded from the operation of the [bankruptcy] law in 1910 (c. 412, $\$ 4,36$ Stat. 838, 839), probably because such corporations could not be liquidated in the ordinary way or by a distribution of assets. A railway is a unit; it can not be divided up and disposed of piecemeal like a stock of goods. It must be sold, if sold at all, as a unit and as a going concern. Its activities can not be halted because its continuous, uninterrupted operation is necessary in the public interest; and, for the preserva. tion of that [public] interest, as well as for the protection of the various private interests involved, reorganization was evidently regarded as the most feasible so. lution whenever the corporation had become "insolvent or unable to meet its debts as they mature."

Continental Ill. Nat'l Bank \& Trust Co. v. Chicago, R.I. \& Pac. Ry., 294 U.S. 648, $671-72$ (1935).

[A] proceeding under $\S 77$ is not an ordinary proceeding in bankruptcy. It is a special proceeding which seeks only to bring about a reorganization, if a satisfactory plan to that end can be devised.

Id. at 676 (emphasis added).

73. See 11 U.S.C. $\$ 22$ (1970) (excluding railroad, insurance, banking, and municipal corporations and building and loan associations from eligibility as bankrupts). 


\section{Abandonment Regulation, Ratemaking, and Confiscation}

The statute that imposes the requirement of continued service on railroads in interstate commerce is $\S \mathrm{I}(18)$ of the Interstate Commerce Act:

[N]o carrier by railroad subject to this chapter shall abandon all or any portion of a line of railroad, or the operation thereof, unless and until there shall first have been obtained from the Commission a certificate that the present or future public convenience and necessity permit of such abandonment. ${ }^{7 t}$

An abandonment for which permission has not been obtained can be enjoined, and subjects the person who directed the abandonment to criminal penalties. ${ }^{\text {To }}$

By the terms of the Act, the permission of the ICC must be obtained for any abandonment, whether a railroad wishes to cease operations on one branch only, ${ }^{76}$ or to shut down its entire system. ${ }^{77}$ Thus, the

74. 49 U.S.C. $\$ 1(18)(1970)$ (cnacted by the Transportation Act of Feb. 28, 1920, ch. $91, \S 402,41$ Stat. $477-78)$. Interestingly, $\$ 1(18)$ is quite similar in wording to the state statute in Eastern Texas which the Court felt compelled to confine to other railroads in order to find a constitutional right to abandon the Eastern Texas Railroad. "[N]or shall the main track of any railroad once constructed and operated be abandoned or removed." Act of Mar. 29, 1889, ch. 24, \$ 1, [1889] Gen. Laws of the State of Texas 20. The Eastern Texas Court held that the scope of this statute was confined to railroads sold under judicial decree. Railroad Comm'n v. Eastern Tex. R.R., 264 U.S. 79, 88-89 (1924).

The ICC is given discretion over the issuance of abandonment certificates by $\S 1(20)$ :

The Commission shall have power to issue such certificates as prayed for, or

to refuse to issue it, or to issue it for a portion or portions of a line of railroad,

or extension thereof, described in the application, or for the partial exercise only of

such right or privilege, and may attach to the issuance of the certificate such terms

and conditions as in its judgment the public convenience and necessity may require.

19 U.S.C. $\$$ I (20) (1970). On ICC abandonment regulation, see generally C. CHERINGToN, supra note 35, at 80-98, 119-88; M. ConsNt, RaIlroad Mergers and Abandonments 118-31 (1964); W. Jones, C.ases and Materials on Regulated Industries 388-93 (1967); Kalmbach, supra note 46, at 121-26; Weissman, Railroad Abandonments: The Competilive Ideal, 43 MINN. L. Rev. 251 (1958); Weissman, Railroad Abandonments: The Impact of Competition, 44 Iow. L. REv. 492 (1959).

75. 49 U.S.C. $\$ 1(20)(1970)$

76. Sce, e.g., Northwestern Pac. R.R. v. United States, 228 F. Supp. 690 (N.D. Cal.) (per curiam), aff'd per curiam sub nom. Northwestern Pac. R.R. v. ICC, 379 U.S. 132 (1964) (sustaining ICC's denial of permission to abandon 2.5 mile portion of track); Purcell v. United States, 41 F. Supp. 309 (D. Md. 1941), aff'd, 315 U.S. 381 (1942) (sustaining ICC order permitting Baltimore \& Ohio Railroad Company to abandon 19.8 miles of track, parts of which were to be flooded by federal reservoir).

77. Sce, e.g., Meyers v. Jay St. Connecting R.R., 259 F.2d 532, 535 (2d Cir. 1958) (sustaining injunction against "total abandonment" by Jay Street Railroad because ICC permission had not been obtained); City of New York v. United States, 344 F. Supp. 929 (E.D.N.Y. 1972) (three-judge court) (sustaining ICC order permitting abandonment of the entire operation of Bush Terminal Railroad Company); Illinois $v$. United States, 213 F. Supp. 83 (N.D. Ill. 1962), aff'd per curiam, 373 U.S. 378 (1963) (sustaining ICC order permitting Chicago, North Shore $\&$ Milwauke Railroad to abandon entire system); Missouri \& Ark. Ry., 271 I.C.C. 171 (1948) (approving abandomment of entire 330 mile operation). 
service obligations imposed by the Interstate Commerce Act are not simply a condition which must be fulfilled by a railroad that wishes to continue operations on some part of its lines; rather they enforce a dedication of indefinite duration on any capital committed to a railroad system..$^{78}$ The abandonment provisions continue to apply even when a railroad is in $\$ 77$ reorganization. ${ }^{79}$

The statutory criterion for abandonment is that it be consistent with "public necessity and convenience." ${ }^{30}$ The test is also formulated as whether the burden on interstate commerce ${ }^{81}$ imposed by uneconomical rail operations is "undue": that is, whether the financial burden on the carrier imposed by continuing services is outweighed by the hardship which abandonment would work on local communities, businesses, shippers, and passengers dependent on rail service. If little or no public inconvenience would result, the ICC is free to allow an abandonment even where the carrier could readily absorb the financial burden of continued operation. ${ }^{82}$

However, if abandonment of all or part of a railroad's operation would lead to serious hardship, the ICC may treat the abandonment request far more stringently. The railroad, first of all, has the evidentiary burden of proving the losses which continued service would cause. ${ }^{83}$ Abandonment can be denied or delayed to permit an experi-

78. "A part of the capital dedicated to a railroad enterprise cannot withdraw itsclf without authorization any more than all of the capital can withdraw itsclf and abandon the railroad without approval." Schwabacher v. United States, 334 U.S. 182, 201 (1918) (minority preferred stockholders of a railroad cannot redeem their stock at par plus accrued unpaid dividends in a merger approved under $\$ 5$ of the Interstate Commerce Act, 49 U.S.C. $\$ 5$ (1970), despite provision of corporate charter guaranteeing redemption in the event of a "winding-up").

79. Bankruptcy Act $\$ 77(0)$, 11 U.S.C. $\$ 205(0)(1970)$.

80. See.Colorado v. United States, 271 U.S. 153, 168 (1926) (Brandeis, J.).

81. The abandonment provision was placed squarely within Congress's power to regulate interstate commerce by the reasoning that running uneconomical or unnecessary lines would weaken a railroad's ability to function as an interstate carricr. Sce id. at 162-63. In the regulation of total abandonment of operations by an interstate caxier, the connection to interstate commerce can be demonstrated by showing that abandonment would divert traffic to other carriers and thereby improve their ability to maintain operations, or that the absence of sufficient revenue for maintenance would affect the safety of interstate passengers. See Illinois v. United States, 213 F. Supp. 83, 90-91 11.4 (N.D. Ill. 1962).

82. See, e.g., Colorado v. United States, 271 U.S. 153, 168 (1926); Purcell v. Unitcd States, 315 U.S. 381, 384-85 (1942) (sustaining ICC decision allowing abandonment of line displaced by flood control project even though cost of relocation would be borne by Government and line had not been operating at a loss); Nebraska ex rel. Nebraska Ry. Comm'n v. United States, 255 F. Supp. 718, 723 (D. Neb. 1966). See also Southern Ry. v. North Carolina, 376 U.S. 93 (1964).

83. See Wellsville, A. \& G.R.R., 338 I.C.C. 604, 609 (1971); Pere Marquette Ry., 72 I.C.C. 303, 307 (1922) ("Where losses are claimed we cannot accept the carrier"s con1clusions as to such losses, but must have before us the items thereof in sufficient detail to leave no reasonable doubt as to the justification for the carrier's claim.")

In the proposed abandonment of a single line that is part of a carrier system, proving 
mental period to test whether the losses are temporary or avoidable. ${ }^{\text {st }}$ A railroad may be required to attempt to stem the losses by renegotiating its division of fares with other carriers, ${ }^{s \bar{v}}$ by applying for a change of rate schedule, ${ }^{80}$ or by applying to local authorities for tax relief $^{87}$ and other governmental aid. ${ }^{\mathrm{ss}}$ An abandonment application can be denied if the ICC believes the market conditions leading to losses were abnormal or are likely to change in the future. ${ }^{89}$

In the case of a railroad running at an unavoidable loss systemwide, abandonment proceedings can involve a process curiously similar to the Rail Act's selection of limited properties for the new Conrail

losses attributable to that line can be a complicated and controversial matter. See, e.g., Wellsville A. \& G.R.R., supra at 607 (rejecting application for abandonment of 50 percent of track because railroad failed to credit to the line any portion of revenues derived from freight car leases or bridge traffic and charged against that line as much as 75 percent of total maintenance expenses); Rood, Protecting the User Interest in Railroad Rcorganization, 7 L.Aw \&. ConteMp. Pron. 495, 503-04 (1940) (criticizing standards applied in abandonment of the Old Colony rail lines during first New Haven reorganization, because no notice taken of the effect of deliberate diversion of traffic from Old Colony to main New Haven routes).

84. See Colorado v. United States, 271 U.S. 153, 160 (1926) (abandonment initially clenied by ICC for a year with leave to renew " "if the improvement in opcrating results, confidently anticipated by protestants, should not materialize." ); C. CHERINGToN, supra note 35, at 126 ("On occasion the Commission has found that, although losses are being incurred, the applicant has failed to discount the influence of temporary factors, and has held that the abandonment should be postponed pending further developments.") (footnote omitted).

85. See, e.g., Brooklyn E. Dist. Terminal v. United States, 302 F. Supp. 1095, 1101 (E.D.N.Y. 1969); Wellsville A. \& G.R.R., 338 I.C.C. 604, 608 (1971).

86. See Chicago N.S. \& M. Ry., 312 I.C.C. 99, 102 (1960) (though entire North Shore had sustained large operating losses for over 30 years, with exception of war years, ICC deferred action on abandonment application for one ycar, during which North Shore was to apply for rate increase and attempt to reduce operating expenses); Southern Pac. Co., 333 I.C.C. 525, 550, 558 (1968) (carrier should seck additional fare increase to reduce deficit on passenger train operation).

87. See, e.g., Colorado \& S. Ry., 166 I.C.C. 470, 492 (1930) (application for abandonment of branch line denied, with possibility of renewal after threc years, to test prospects of traffic growth and to allow railroad to attempt to reduce expenses and scek tax relief).

88. See Southern Pac. Co., 333 I.C.C. 525, 547 (1968) ("No attempts were made to determine which governmental officials had authority and jurisdiction over meaningful programs of public assistance and subsidies, or who would be in a position to originatc and propose necessary legislative action to implement such programs.")

89. See Wellsville A. \& G.R.R., 338 I.C.C. 604, 608 (1971) ("tcstimony of shippers, receivers of freight, and public witnesses" showed "definite possibilities of an increase in the volume of business"); Missouri Pac. R.R., 307 I.C.C. 189, 199-200, 207 (1959) (ICC rejected conclusion that branch line could not be operated profitably, because freight traffic in farming area had been abnormally low from drought and temporary local storage of grain); Pennsyliania, O. \& D.R.R., 236 I.C.C. 490, 497 (1939) (branch abandonment denied because opcrating loss was duc to carrier's practice of handling branch traffic "over a more circuitous route" and carricr's failure to maintain full service, leading to loss of traffic). See also Southern Pac. Co., 333 I.C.C. 525, 558 (1968) (recent patronage decline rejected as evidence of a "hopeless long-run outlook" for passenger service because carrier had made "little effort to attract passengers" despite possible substantial market; application for partial scrvice cutback under 49 U.S.C. \$ 13a(1) (1970) was refused). 
system. Where the carrier proposes complete abandonment despite the fact that the amount of traffic varies on different lines or sections, the ICC can refuse permission to abandon the portions with heaviest traffic which might run profitably as a scaled-down system, and allow abandonment of the rest. ${ }^{90}$

That an applicant for abandonment faces the burden of proving future losses does not foretell how far below current liquidation value erosion can constitutionally proceed; an abandonment hearing itself might be subject to dismissal if delay seemed arbitrary. But if there is genuine doubt about the inevitability of the losses supporting an abandonment, or if profitable operation of some of the system seems possible by paring arvay unprofitable lines, then part of the operating losses incurred in testing those possibilities would probably be borne by the railroad's estate. Liquidation value-which assumes no burden can be placed on an applicant for abandonment-thus seems too high to be the entitlement of Conrail railroads.

Where an abandonment-partial or total-is found to be inconsistent with the public convenience and necessity, the statute on its face allows the ICC to refuse a certificate of abandonment to the carrier and to insist that the capital remain in its present use. But refusal of abandonment, like any other regulatory practice, is limited by the Fifth Amendment; one is thrown back to the question of what constitutes confiscatory denial of abandonment. One source in judging the entitlement of stockholders in an abandonment refusal is the standards governing ratemaking. If the action of a regulatory commission in limiting a railroad's rate of return by setting a rate schedule is nonconfiscatory, then so must be the limitation of rate of return by denial of partial or total abandonment. Further, where a regulatory commission engages in the activity of setting rates in an industry subject to requirements of continued service, the implicit premise of the exercise must be that it is proper to require service under those circumstances.

In ratemaking, there is no longer any ground for a regulated com-

90. 49 U.S.C. $\S 1(20)(1970)$ allows the ICC to choose to grant only part of a carricr's request for abandonment: the Commission may issue a certificate of abandonment "for a portion or portions of a line of railroad ... described in the application, or for the partial exercise only of such right or privilege ...."See, e.g., Thornton \& A. Ry., 138 I.C.C. 416, 424 (1928) (application for complete abandonment accepted only in part); Eastern Ky. Ry., 111 I.C.C. 476 (1926) (though railway had significant operating deficits for six of previous 10 years, had never paid any dividends to stockholder:, and had required cash advances from stockholders to meet operating deficits, application for complete abandonment was allowed only in part; more populated southern portion of railway to be operated independently for a year to sce whether it could meet expenses); C. Cheringron, supra note 35 , at 145 . 
pany to contend that it has a constitutional right to an earnings stream whose present value equals liquidation value as such. FPC v. Hope Natural Gas Co. ${ }^{91}$ and FPC v. Natural Gas Pipeline Co. ${ }^{92}$ established that a rate base can be founded on any of a number of measures, ${ }^{93}$ and that a rate of return need not have a capitalized value equal to reproduction value. ${ }^{94}$ By the same logic, a rule requiring capitalized earnings to equal liquidation value would have to be rejected, for it too would tie regulated rates to a single inflexible formula.

Natural Gas Pipeline and Hope also established that actual historical investment was an acceptable rate base. ${ }^{95}$ Historical cost has subsequently become the basis most commonly used for rate calculations. ${ }^{.0} \mathrm{~A}$ rule requiring that capitalized earnings equal liquidation value would inconsistently divorce rates from any relationship to historical investment. ${ }^{97}$

91. 320 U.S. 591 (1944).

92. 315 U.S. 575 (1942).

93. In Natural Gas Pipeline the Court noted:

The Constitution does not bind rate-making bodies to the sersice of any single formula or combination of formulas. Agencies to whom this legislative power has been delegated are free, within the ambit of their statutory authority, to make the pragmatic adjustments which may be called for by particular circumstances.

FPC v. Natural Gas Pipeline Co., 315 U.S. 575, 586 (1942). See also FPC v. Hope Natural Gas Co., 320 U.S. 591, 602 (1944) ("It is not theory but the impact of the rate order which counts.")

94. The radical character of Hope and Natural Gas Pipeline was in overthrowing the stringent "fair value" standard of early ratemaking. The effect was "to lay the ghost of Smyth v. Ames [169 U.S. 466 (1898)]," as Justices Black, Douglas, and Murphy put it. FPC v. Natural Gas Pipeline Co., 315 U.S. 575, 602 (1942) (concurring opinion). The Smyth rule had required regulatory commissions to base a utility's rate of return on a "fair value" of the property which gave considerable weight to reproduction cost. Sce id. at 60t-05 (Black, Douglas \& Murphy, JJ., concurring); Missouri ex rel. Southwestern Bell Tel. Co. v. Public Serv. Comm'n, 262 U.S. 276, 289-90 (1923) (Brandeis \& Holmes, JJ., dissenting).

The flexibility left to rate commissions by Natural Gas Pipeline and Hope scems to forbid courts from requiring any single formula such as reproduction value. See FPC v. Natural Gas Pipeline Co., supra at 606 (Black, Douglas, and Murphy, JJ., concurring) ("As we read the opinion of the Court, the Commission is now freed from the compulsion of admitting evidence on reproduction cost or of giving any weight to that element of 'fair value." "); FPC v. Hope Natural Gas Co., 320 U.S. 591, 628 (I944) (Jackson, J., concurring in part and dissenting in part) ("Cextainly the theory of the court below that ties rate-making to the fair-value-reproduction-cost formula should be overruled as in conflict with [Natural Gas Pipeline].") (footnote omitted).

95. FPC v. Natural Gas Pipeline Co., 315 U.S. 575, 606 (1942) ("The Commission may now adopt, if it chooses, prudent investment as a rate base-the base long advocated by Mr. Justice Brandeis. . . [T]here could be no constitutional objection if the Commission adhered to that formula and rejected all others."); FPC v. Hope Natural Gas Co., 320 U.S. 591, 628 \& $\mathrm{n} .2$ (1914) (Jackson, J., concurring in part and dissenting in part).

96. See L. Weiss, Case Studies in AMerican INdustry $108-09$ \& n.12 (2d ed. 1971 ).

97. Use of either liquidation value or reproduction value as a rate base entails the assumption that investors' entitlement in ratemaking extends to any increase in the market value of property used in the regulated business. This assumption was criticized harshly by Justices Brandeis and Holmes in their Southwestern Bell dissent, grandfather of Hope and Natural Gas Pipeline: 
This rejection of liquidation value as a standard for stockholders' entitlement in ratemaking is more than a question of mere labeling. It is true, of course, that Hope and other cases stress the desirability of maintaining the financial integrity of a regulated company-of assuring a rate of return high enough to allow the business to attract new equity needed for expansion or refinancing: ${ }^{\text {as }}$ But the Hope standard of attracting capital is in fact applicable only where the industry is capable of earning a great deal and a regulatory commission is holding down its earnings. A more flexible standard has applied where an industry is doing badly for economic reasons, and where under any rate schedule the rate of return would be low. ${ }^{99}$

The thing devoted by the investor to the public use is not specific property, tangible and intangible, but capital embarked in the enterprise. ... The several items of property constituting the utility, taken singly, and freed from the public use, may conceivably have an aggregate value greater than if the items are used in combination. The owner is at liberty, in the absence of controlling statutory provision, to withdraw his property from the public service; and, if he does so, may obtain for it exchange valuc. . . But so long as the specific items of property are employed by the utility, their exchange value is not of legal significance.

262 U.S. at 290 (footnote omitted). Treating liquidation value as the standard would introduce two peculiar kinds of arbitrariness into ratemaking: the constitutionally minimum rate of return would depend on the level of inflation of the current value of assets over their historical cost, and on the relative salvageability of the property. Though two businesses might have the same historical investment, a more remunerative rate schedule could be demanded by the business whose cquipment had increased most in value and was more easily removed and marketed.

98. FPC v. Hope Natural Gas Co., 320 U.S. 591, 605 (1944):

Rates which enable the company to operate successfully, to maintain its financial integrity, to attract capital, and to compensate its investors for the risks assumed certainly cannot be condemned as invalid, even though they might produce only a meager return on the so-called "fair value" rate base.

See FPC v. Natural Gas Pipeline Co., 315 U.S. 575, 607 (1942) (Black, Douglas \& Murphy, JJ., concurring); Missouri ex rel. Southwestern Bell Tel. Co. v. Public Serv. Comm'n, 262 U.S. 276, 291 (1923) (Brandeis \& Holmes, JJ., dissenting); New England Tel. \& Tel. Co. v. Department of Pub. Util., 327 Mass. 81, 94, 97 N.E.2d 509, 516 (1951).

99. See FPC v. Hope Natural Gas Co., 320 U.S. 591, 603 (1944), quoling FPC v. Natural Gas Pipeline Co., 315 U.S. 575, 590 (1942) ("'regulation does not insure that the business shall produce net revenues" "). In Natural Gas Pipeline, the Court affirmed the FPC's refusal to include the maintenance cost of excess capacity in the rate base of a utility company brought under regulation for the first time, even though such an exclusion would reduce the company's revenues. "[T]he hazard that the property will not earn a profit remains on the company in the case of a regulated, as well as an unregulated, business." FPC v. Natural Gas Pipeline, supra at 590 .

The strongest statement of the defeasibility of the Hope standard of maintaining credit and attracting capital occurred in Market St. Ry. v. Railroad Comm'n, 324 U.S. 548 (1945). In setting rates for a failing cable car system, the California Railroad Commission refused the railway's request for a seven cent fare, instead setting the fare one cent lower. In justifying this as yielding an adequate return, the Commission refused to consider as a rate base either capitalization, historical cost, or reproduction value; rather it chose the much lower price at which the railway had offered to sell its properties to the city of San Francisco. The Railroad Commission predicted a six percent rate of return on the shrunken rate base; the rate of return earned upon the face value of the securities would have been only 1.26 percent. The higher fare would have increased the rate of return to 9.6 percent on the shrunken rate base, and 2.01 percent 
Indeed, one line of case law-the "net loss" cases-seems to rule out a claim of confiscation by shareholders so long as a carrier is returning any earnings on equity. In Baltimore i Ohio Railroad $v$. United States, ${ }^{100}$ the Court upheld a noncompensatory freight rate for certain fresh vegetables against a Fifth Amendment challenge by noting that there was

no claim that the challenged rates will make any one of the com-

plaining railroads operate its entire business at a loss . ...

... So long as a railroad is not caused by such regulations to lose money on its over-all business, it is hard to think that it could successfully charge that its property was being taken for public use "without just compensation."101

The "net loss" test for confiscation was also adopted in Northwestern Pacific Railroad $v$. United States, ${ }^{102}$ a case which transposed the standard from ratemaking to abandonment. The Northwestern challenged an ICC order denying its request to abandon a portion of railroad line, because maintaining service on the line required rebuilding

on the face value of the securities. The company could not possibly attract new equity under such rates, but the Court declared that the Hope standard was inapposite.

[The] considerations, advanced in [Hope] (which was reviewed pursuant to statute rather than under the Fourteenth Amendment), concerned a company which had advantage of an economic position which promised to yield what was held to be an excessive return on its investment and on its securities. They obviously are inapplicable to a company whose financial integrity already is hopelessly undermined, which could not attract capital on any possible rate, and where investors recognize as lost a part of what they have put in. . . There was no suggestion [in Hope] that less might not be allowed when the amount allowed was all that the company could earn.

$I d$. at 566 . It should be noted that the $\$ 7.9$ million figure used as a rate base in Market Street Railway was not liquidation value in its conventional sense, that is, what the property of the railway would have yielded if sold for scrap. Rather, it was the preliminary negotiated price for sale of the operating railway to the city of San Francisco. As part of that transaction, the railway was relieved of its obligation to continue operations, return on which was likely to be low. (The railway had operated at an intermittent deficit since at least 1938 and had already been denied permission to abandon several unprofitable lines. See Market St. Ry. v. Railroad Comm'n, 24 Cal.2d 378, $385,386,150$ P.2d 196, 201 (1944).)

See also Reagan v. Farmers' Loan \& Trust Co., 154 U.S. 362, 412 (1894); Democratic Cent. Comm. v. Washington Metropolitan Area Transit Comm'n, 485 F.2d 886, 912 (D.C. Cir. 1973), cert. denied, 415 U.S. 935 (1974).

100. 345 U.S. 146 (1953) (Black, J.).

101. Id. at 148 (footnote omitted). Justice Douglas and Chief Justice Vinson dissented in Baltimore \& Ohio, not on the ground that Justice Black's test for a confiscatory rate of return was too harsh in allowing a very low return on invested capital system-wide, but rather on the ground that any rate for a class of commodities which did not cover costs was probably unreasonable and arbitrary.

For another ratemaking case where the "net loss" test for confiscation was adopted, sce Pan Am. Airways, Inc. v. CAB, 256 F.2d 711 (D.C. Cir.), cert. denied, 35S U.S. 836 (1958).

102. 22S F. Supp. 690 (N.D. Cal.) (three-judge court) (per curiam), aff'd per curiam sub nom. Northwestern Pac. R.R. v. ICC, 379 U.S. 132 (1964). 
a collapsed railroad tunnel. The three-judge district court ruled per curiam that the railroad could not make a claim of confiscation so long as it would not incur long run losses in its overall system. ${ }^{103}$ There was no confiscation, explained the court, where the question was "actually one of degree of profits as opposed to over-all net loss."1"1

The net loss cases would seem to sustain the view that permission to abandon rail service can constitutionally be denied even though railroad stockholders are earning a very low return or even no return at all on their investment. If this is so, then stockholders of the railroads included in Conrail would seem to have only limited ground to complain of a taking should Conrail's estimated going-concern value be less than liquidation value-for a similar shortfall in capitalized earnings would not have been confiscatory had the original railroads continued in operation indefinitely. ${ }^{105}$

The entitlement of creditors seeking abandonment is more ambiguous. Ratemaking in its conventional Hope setting does not provide much guidance, since a company by definition must be solvent in order to have any return on equity. However, there are other guides.

First, there is a telling practice in ICC abandonment proceedings. To demonstrate that a line is running at a loss and hence is suitable for abandonment, a carrier cannot count as expenses either depreciation $^{106}$ or normalized maintenance ${ }^{107}-$ even though these may be

103. [W] have no reason to think that the Supreme Court would not adopt the same standard of confiscation for abandonment cases that it has adopted for rate cases. Consequently, we hold that no confiscation results from an order of the Interstate Commerce Commission denying the abandonment of rail services which arc shown to be unprofitable, as long as there is no net loss to the over-all system. 228 F. Supp, at 694 .

104. Id. Though the Northwestern Railroad's net income would in fact have becil increased by resuming service, id., its parent corporation, the Southern Pacific Railway, would have enjoyed larger net revenues in the event of an abandonment. Id. at 693 . Thus, the court's adoption of the net loss theory was not dicta.

The railroad challenged net loss doctrine on appeal and in application for rehearing (see Jurisdictional Statement for Appellant at 3, Northwestern Pac. R.R. v. ICC, 379 U.S. 132 (1964); Petition for Rehearing for Appellant at 2), but the decision was affirmed without opinion. 379 U.S. 132 (1964) (per curiam), rehearing denied, 379 U.S. 984 (1965).

105. Admittedly, in a situation where abandonment permission was denied and the same railroad company continued in operation indefinitely, the stockholders of the old railroad would retain a residual claim on any unanticipated upside gain and on any value left in a future liquidation. In contrast, when the assets of the railroad are exchanged for Conrail securities and these are distributed among investors according to the absolute priority rule, some or all stockholders may be wiped out, with no residual claim in the event of unexpectedly successful Conrail operations or future liquidation.

106. See Chicago \& N.W. Ry., 275 I.C.C. 759, 773-74 (1951) (depreciation on roadway structures not considered a savable expense); New Mexico Cent. Ry., 233 I.C.C. 147, 149 (1939).

107. See New York, N.H. \& H.R.R., 324 I.C.C. 345, 351 (1965) (normalized maintenance cannot be counted as out-of-pocket expense to determine whether opcrations of branch line of insolvent carrier have been profitable; minimum expenditures necessary for safe operations in next five years are of "primary importance" in determining public convenience and necessity). 
necessary to preserve the value of creditors' security. At least at times, the concern seems to be for out-of-pocket operating expenses necessary for keeping the line in physical operation. ${ }^{108}$

Second, a strong argument can be made that the abandonment rights of the estate of a railroad should not depend on the particular capitalization with which the railroad financed its investment in transportation property. If the classification of the source of investment as debt or equity determines what amount must be earned in net operating income in order to deny abandonment, it would oddly bias the usual criteria for the railroad's choice of capital structure. For instance, in a railroad company that was solvent but economically unprofitable, the equity owners would greatly increase their advantage by selling themselves bonds (essentially an internal exchange offer of bonds for stock). After any subsequent default, they could apply for abandonment and demonstrate that the same shortfall-the difference between liquidation value and going-concern value-against which they had no complaint as equity orwers now amounted to an unconstitutional taking. "Leveraging," in times of industry decline, would take on a new and peculiar sense. Apart from such overt manipulation, an extreme difference in abandonment entitlement between debt and equity would introduce arbitrariness into the capitalizations that the ICC would allow in financings and in conventional reorganizations. Though using debt as some proportion of the capitalization would minimize the cost of capital, it would carry with it the great disadvantage of mandating abandonment of service in situations where equity capital would not.

The dependence of the cost of any form of capital on the extent of its right to precipitate abandonment is apparent. But where the "purchased expectations" of bondholders are not clear, it seems un-

108. In at least one application for complete abandonment, reviewed by a threejudge court under Judge Friendly, the standard used for allowing abandonment ultimately came fairly close to actual operating expenses. In City of New York v. United States, 337 F. Supp. 150 (E.D.N.Y. 1972), users of the Bush Terminal Railroad tried to annul an ICC order authorizing complete abandonment. The proceeding was remanded to the ICC for consideration of the environmental impact of abandonment; given the remand, the ICC was directed to consider as well whether the offer of rail users to pay a $\$ 25$ surcharge would adequately ameliorate the carrier's financial problems. Id. at 162-63. The ICC again authorized abandonment, and the court affirmed. City of New York v. United States, 344 F. Supp. 929 (E.D.N.Y. 1972). But it is interesting to note that the case for denial of abandonment was evidently regarded as an arguable one by the court. "[W]e do not find the case for abandonment of the Railroad's operations quite so overwhelming as the Commission's supplemental report suggests .... Id . at 933. If operations could have been brought to the break-even point, an immediate source of capital found for equipment rehabilitation and replacement, and some amount set aside toward the gradual repayment of the railroad's current liabilities, the tenor of the opinion suggests that the court might have sustained an ICC order denying abandonment. 
desirable, by retrospective divination, to introduce a rigid difference between the abandonment rights of debt and equity. Where Congress has wished to allow for a form of financing with ironclad security, it has been able to do so explicitly, as in the provision for exclusion of equipment trust financing from any modification of terms in $\$ 77$ reorganizations ${ }^{109}$ or the Conrail reorganization. ${ }^{110}$ One wonders also how one would define, in a scheme of rigid differentiation, the abandonment rights of unsecured creditors, or of secondary debtorscorporations whose sole function is to lease lines to an operating rail company and distribute the lease rental among their own shareholders. The secondary debtor is an unsecured creditor of the main operating company, yet its owners are mere equity holders.

Finally, as noted in the initial discussion of the Brooks-Scanlon cases, the only adjudicated instances of a constitutional right to abandon involve railroads which could not be made to yield any net operating income whatever. ${ }^{111}$ That such precedent should be extended to give bondholders a right to the proceeds of a dismantling whenever debt service is impaired seems the more radical act.

109. Bankruptcy Act $\S 77(j), 11$ U.S.C. $\$ 205(j)$ (1970).

110. Rail Act $\$ 303(b)(3)$, 45 U.S.C. $\$ 743(b)(3)$ (Supp. IV 1974).

111. See note 31 supra. 